\title{
Presidential Lecture of the Japanese Association for Chest Surgery in 2019
}

\author{
Masayuki Chida
}

The Japanese Association for Chest Surgery, Kyoto, Japan

Correspondence to: Masayuki Chida, MD, PhD. Department of General Thoracic Surgery, Dokkyo Medical University, 800 Kitakobayashi, Mibu, Tochigi 321-0293, Japan. Email: chidaths@dokkyomed.ac.jp.

Received: 27 November 2019; Accepted: 27 December 2019; Published: 05 April 2020.

doi: 10.21037 /jovs.2019.12.03

View this article at: http://dx.doi.org/10.21037/jovs.2019.12.03

The Japanese Association for Chest Surgery, JACS, was established in 1984. The Japanese Association for Thoracic Surgery, JATS, was founded in 1964 by thoracic surgeons, but cardiovascular surgeon came to occupy a large number, and it was necessary to establish a society exclusively for thoracic surgeon. And we use the name "Chest" instead of "Thoracic" for the academic society, because abdominal surgeons do esophageal surgery in Japan. In this meaning, thoracic surgery usually means chest surgery in Japan. Both cardiovascular surgeons and thoracic surgeons are members of the Japan Surgery Society, JSS. JSS has about 40,000 members, and JACS accounts for about $8 \%$ of the JSS membership.

I am going to summarize the current activities of JACS in this article.

The number of JACS members is about 3,200 and has been almost flat since 2000. On the other hand, the number of operations in the thoracic surgery field was about 40,000 in 2000, but doubled in 2016 to 80,000 . There are over 50,000 lung malignancies surgery and over 40,000 primary lung cancer surgery.

The percentage of female members at our society is $8.4 \%$, the ratio of female board-certified thoracic surgeon is $5.9 \%$, and the ratio of female councilors of JACS is $2.3 \%$. Currently, the percentage of female students in medical school exceeds $30 \%$, and it is important to increase the percentage of female thoracic surgeons. Many female surgeons withdraw in their 30 s, and childbirth and childcare, and the work-life balance associated therewith, seem to be a barrier. We believe that there will be a need for policies such as a grace period for obtaining the board-certification.

In Japan, the category of video-assisted thoracic surgery, VATS, included "true" VATS and hybrid surgery with small open thoracotomy (4-8 $\mathrm{cm}$ in skin incision) using combined of direct and video vision, but now we have separate statistics and counts "true" VATS as VATS. And "true" VATS is the majority of procedures for lung cancer now. As a result, opportunities for young surgeons to experience open chest surgery have decreased, and this has become an issue for medical safety.

Robot-assisted thoracic surgery, RATS, is also rapidly spreading because it has been covered by national insurance since 2018 in Japan, and it seems that about 10\% of lung cancer surgery is performed by RATS in 2019. Procter system for first several cases and pre-registration of all cases are conducted to safely introduce RATS at each hospital. There have been no major accidents under the proctor system, but there have been some reports of serious accident in subsequent surgery. However, at present, we think that the risk of RATS does not exceed the usual surgical risk of lung cancer, but careful observation is necessary and we pay attention to risk control of RATS.

In international affairs, we have deepened relationship with the European Society of Thoracic Surgeons, ESTS, and mutual ESTS-JACS joint sessions and JACS-ESTS joint sessions have become established well. Also, in view of the prosperity of single-port VATS in Asia, JACS has sent young members to hospitals in Shanghai for a week as JACS fellowship. JATS fellowship, on the other hand, dispatches to hospitals at Europe and the United States on a monthly basis. Regarding the issue of making center of Asian thoracic surgeons, establishment of the Asian Society of Thoracic Surgeons, ASTS, was temporarily considered, but it was canceled. When Asia Thoracoscopic Surgery Education Program, ATEP, was held at Bangkok in February 2019, 
it was confirmed that Asian thoracic surgeons should join in thoracic domain of the Asian Society for Cardiovascular and Thoracic Surgery, ASCVTS, and raise our society up, because Prof. Jheon from Korea, a crucial member of ATEP, has become the President of ASCVTS.

\section{Acknowledgments}

Funding: None.

\section{Footnote}

Provenance and Peer Review: This article was commissioned by the Guest Editor (Meinoshin Okumura) for the series "Dedicated to the 36th Annual Conference of Japanese Association for Chest Surgery (JACS)" published in Fournal of Visualized Surgery. The article has undergone external peer review.

Conflicts of Interest: The author has completed the ICMJE uniform disclosure form (available at https://jovs.

doi: 10.21037 /jovs.2019.12.03

Cite this article as: Chida M. Presidential Lecture of the Japanese Association for Chest Surgery in 2019. J Vis Surg 2020;6:24. amegroups.com/article/view/10.21037/jovs.2019.12.03/ coif). The series "Dedicated to the 36th Annual Conference of Japanese Association for Chest Surgery (JACS)" was commissioned by the editorial office without any funding or sponsorship. The author has no other conflicts of interest to declare.

Ethical Statement: The author is accountable for all aspects of the work in ensuring that questions related to the accuracy or integrity of any part of the work are appropriately investigated and resolved.

Open Access Statement: This is an Open Access article distributed in accordance with the Creative Commons Attribution-NonCommercial-NoDerivs 4.0 International License (CC BY-NC-ND 4.0), which permits the noncommercial replication and distribution of the article with the strict proviso that no changes or edits are made and the original work is properly cited (including links to both the formal publication through the relevant DOI and the license). See: https://creativecommons.org/licenses/by-nc-nd/4.0/. 